\author{
INFO ARTIKEL \\ Riwayat Artikel: \\ Diterima : 01 Desember 2019 \\ Disetujui : 25 Februari 2020
}

GEOGRAFI

\title{
KONDISI SOSIAL EKONOMI PEKERJA WANITA SEKTOR INFORMAL DI KECAMATAN TALANG UBI
}

\author{
Dini Afriyanti ${ }^{1}$, Mirna Taufik ${ }^{2}$, Misdalina $^{3}$ \\ ${ }^{1}$ SDIT Insan Mulia Palembang \\ ${ }^{2}$ Program Studi Pendidikan Geografi, Universitas PGRI Palembang \\ ${ }^{3}$ Program Studi Pendidikan Matematika, Universitas PGRI Palembang \\ $(区)$ dinifrnt @gmail.com ${ }^{1}$, mirnaputridata@yahoo.com ${ }^{2}$
}

\begin{abstract}
ABSTRAK
Wanita aktif dalam kegiatan ekonomi bukan suatu hal yang baru, dengan adanya program kesetaraan gender semakin membuka kesempatan bagi mereka untuk memasuki lapangan pekerjaan baik sektor formal maupun sektor informal. Namun sektor informal lebih banyak dipilih terutama ibu rumah tangga. Penelitian ini bertujuan untuk mengetahui kondisi sosial ekonomi pekerja wanita sektor informal di Pasar Pendopo Kecamatan Talang Ubi. Metode yang digunakan pada penelitian adalah metode deskriptif kualitatif, pengumpulan data melalui wawancara, observasi,dan dokumentasi. Dari hasil wawancara diketahui pendapatan perhari pekerja wanita sektor informal lebih dari Rp. 100.000 dengan tempat usaha milik sendiri, dan jenis dagangan yang berbeda, pendapatan para pekerja wanita digunakan untuk membantu memenuhi kebutuhan hidup keluarga, sedangkan $80 \%$ suami mereka juga bekerja. Dengan pendapatan perhari pekerja wanita sektor informal ditambah dengan pendapatan suami, mereka dapat mencukupi kebutuhan hidup sehari-hari. Sehingga dapat ditarik kesimpulkan kondisi sosial ekonomi pekerja wanita sektor informal di Pasar Pendopo Kecamatan Talang Ubi dapat digolongkan sebagai sosial ekonomi menengah karena dengan adanya bantuan dari pendapatan wanita kebutuhan dalam rumah tangga dapat terpenuhi dengan baik. Berbeda jika tidak adanya bantuan ekonomi dari pekerja wanita dalam keluarga.
\end{abstract}

kata kunci : Sosial ekonomi, Sektor informal, Pekerja wanita.

\begin{abstract}
Active women in economic activities is not a new thing, with the existence of gender equality programs increasingly opening opportunities for them to enter employment both the formal sector and the informal sector. however, the informal sector is mostly chosen, especially housewives. This study aims to determine the socio-economic conditions of informal sector women workers in the Pendopo Market in Talang Ubi District. The method used in this research is descriptive qualitative method, data collection through interviews, observations, and documentation. From the interview results it is known that the daily income of women workers in the informal sector is more than Rp. 100,000 with their own place of business, and different types of merchandise, the income of women workers is used to help meet the needs of family life, while $80 \%$ of their husbands also work. with the daily income of women workers in the informal sector plus the income of their husbands, they can fulfill their daily needs. so it can be concluded that the social economic conditions of women workers in the informal sector in the Pendopo Market in
\end{abstract}


Talang Ubi District can be classified as socioeconomic because of the existence of assistance from women's income needshousehold can be fulfilled well.different if there is no economic assistance from female workers in the family.

keywords: Economic Sector, Informal Sector, Female Workers.

\section{PENDAHULUAN}

Sosial ekonomi merupakan segala sesuatu yang berkaitan dengan pemenuhan kebutuhan yang ada di masyarakat atau yang lebih umumnya terkait dengan kesejahteraan masyarakat. Sosial ekonomi sendiri dapat dilihat dari berbagai hal seperti pekerjaan, pendapatan, dan juga pendidikan dari masing-masing masyarakat. Semakin tinggi pendidikan masyarakat kemungkinan untuk mendapatkan penghasilan tinggi juga semakin besar. Pendapatan yang besar atau tinggi tentunya dapat memnuhi kebutan keluarga seperti kebutuhan sehari-hari, pendidikan anak, dan juga kesehatan keluarga. Berdasarkan hal tersebut masyarakat dapat digolongkan memiliki sosial ekonomi menengah, dan bahkan tinggi. Menurut Koenjaraningrat (1981:35, dikutip dari Zunaidi, 2013:54). Sosial ekonomi setiap anggota keluarga itu berbeda-beda dapat dilihat dari sandang, pangan, papan, pendidikan, kesehatan dan masih banyak lainnya.

Menurut Ramadhan (2003:1) sejak terjadinya krisis ekonomi di Indonesia pada tahun 1998 banyak sekali kegiatan ekonomi yang cenderung beralih pada sektor informal. Menurut Handayani (2009:36-40) krisis moneter yang melanda Indonesia, berdampak pada penutupan pabrik-pabrik. Akibatnya, ribuan buruh harus kehilangan pekerjaannya, padahal pabrik-pabrik tersebut adalah tempat mereka menggantungkan hidup. Sebagian buruh atau pegawai yang mengalami PHK, mereka memutuskan kembali ke daerah asal masing-masing dan melakukan usaha untuk mempertahankan perekonomian keluarga. Hal ini merupakan salah satu cikal bakal berkembangnya kegiatan sektor informal. Masyarakat memilih bekerja sebagai sektor informal sebagai jalan keluar alasannya karena untuk masuk ke dalam sektor informal tidak membutuhkan modal besar, keterampilan, dan pendidikan khusus. Contoh sektor informal yang paling banyak dan dekat dengan keseharian kita adalah PKL (pedagang kaki lima).

Menurut Sidharta (2002, dikutip dari Handayani, 2011:35) Sejak awal tahun 1990-an, mulai dikenal istilah pedagang kaki lima yang identik dengan orang yang menjual dagangan menggunakan gerobak. Sementara pihak lain mendefinisikan PKL sebagai pedagang informal yang menempati kaki lima (trotoar- pedestrian) yang keberadaannya tidak boleh mengganggu fungsi publik, baik ditinjau dari aspek ekonomi, sosial, fisik visual, lingkungan, dan pariwisata.

Pedagang kaki lima sekarang ini sangat dengan mudah ditemui baik di kota besar maupun kabupaten seperti halnya di Kabupaten PALI (Penukal Abab Lematang Ilir) khususnya di pasar Pendopo di Kecamatan Talang Ubi. Para pekerja sektor informal di Pasar Pendopo lebih banyak pekerja wanita jika dibanding pekerja laki-laki. Menurut Farida (2011:104) perkembangan masyarakat menunjukan, bahwa wanita berperan bukan hanya sebagai ibu rumah tangga saja, tetapi mereka turut serta dalam mencari nafkah untuk memenuhi kebutuhan rumah tangganya, sektor informal merupakan pilihan semua kalangan masyarakat, karena semua orang bisa masuk, tanpa harus ada pendidikan formal, tanpa ada keahlian, dan tanpa prosedur yang menyulitkan. Oleh karena itu, di sektor informal wanita nampaknya lebih sesuai dalam melaksanakan perannya selain sebagai ibu rumah tangga juga mampu untuk aktif giat dalam kegiatan ekonomi.

Tidak adanya kriteria tertentu untuk memasuki sektor informal menjadikan sektor informal sebagai suatu jalan keluar untuk memenuhi kebutuhan keluarga, oleh karena itu peneliti tertarik untuk mengetahui alasan memilih bekerja di sektor informal khususnya pekerja wanita di Pasar Pendopo Kecamatan Talang Ubi. 
Menurut Yudha (2017:23) sosial ekonomi adalah segala sesuatu yang berkaitan dengan pemenuhan kebutuhan masyarakat, antara lain sandang, pangan, perumahan, pendidikan, kesehatan, dan lain-lain. Menurut Koenjaraningrat,1981(dikutip dari (Zunaidi, 2013)) sosial ekonomi masyarakat dapat digolongkan berdasarkan kedudukan sosial ekonomi atas, menengah, dan bawah. Menurut Arvenia (2017:28) kondisi ekonomi adalah suatu keadaan dimana pendapatan cukup untuk memenuhi kebutuhan baik primer,sekunder, bahkan kebutuhan tersier sekalipun. Jika seseorang memiliki tingkat pendapatan yang cukup tinggi, maka pemenuhan kebutuhan dapat terpenuhi dengan baik.

Menurut Hidayat (1979, dikutip dari Yunus, 2011:15) sektor informal adalah unit usaha yang tidak memperoleh proteksi ekonomi dari pemerintah. Menurut Pitoyo (2007:129-130) gambaran sektor informal saat ini masih identik dengan aktivitas ekonomi skala kecil, kurang produktif, dan tidak mempunyai prospek yang menjanjikan, tapi bagi masyarakat kecil, sektor informal laksana pahlawan karena dapat dijadikan sumber utama alternatif pendapatan. Ini berarti sektor informal telah memberikan ruang bagi mereka untuk dapat tetap bertahan hidup dari pada predikat pengangguran.

Menurut Farida (2011:104) perkembangan masyarakat menunjukan, bahwa perempuan berperan bukan hanya sebagai ibu rumah tangga saja, tetapi mereka turut serta dalam mencari nafkah untuk memenuhi kebutuhan rumah tangganya, Sektor Informal merupakan pilihan dari semua kalangan masyarakat, karena semua orang bisa masuk, tanpa harus ada pendidikan formal, tanpa ada keahlian, dan tanpa prosedur yang menyulitkan. Menurut Artini dan Handayani (2009, dikutip dari Dewi, 2012:119-120) mengatakan bahwa umumnya perempuan termotivasi untuk bekerja adalah untuk membantu menghidupi keluarga dan umumnya bekerja di sektor informal. Menurut Hakim (2011:24) di sektor informal wanita nampaknya lebih sesuai dalam melaksanakan perannya selain sebagai ibu rumah tangga juga mampu untuk aktif giat dalam kegiatan ekonomi.

\section{METODOLOGI PENELITIAN}

Penelitian dilakukan di Pasar Pendopo Kelurahan Talang Ubi Timur Kecamatan Talang Ubi Kab. Penukal Abab Lematang Ilir (PALI). Penelitian ini menggunakan metode kualitatif, Dalam penelitian ini subjek penelitian adalah pekerja wanita sektor informal. Pada penelitian ini terdapat dua jenis informan yaitu informan umum yakni pekerja wanita sektor informal dan informan kunci untuk mencocokkan informasi yang didapat dari informan umum dengan data yang tercatat dikantor Pasar Pendopo yakni kepala pasar. Teknik pengumpulan data menggunakan wawancara, observasi, dan dokumentasi. Dimana peneliti harus melakukan survei secara langsung ke lapangan. Setelah dilakukan wawancara kemudian menguji validitas data menggunakan cara uji kredibilitas atau kepercayaan terhadap data yang dilakukan dengan menggunakan teknik triangulasi data.

\section{HASIL DAN PEMBAHASAN}

\section{Usia Pekerja Wanita Sektor Informal}

Usia untuk pekerja wanita mengacu pada wanita usia subur (WUS) yaitu 15-49 tahun sesuai dengan yang dikemukakan oleh Ernawati (2018:28). Sesuai dengan hasil penelitian bahwa usia pekerja wanita sektor informal dapat diihat pada gambar 1.

Berdasarkan hasil yang didapat dilapangan dapat diketahui bahwa pekerja wanita sektor informal di Pasar Pendopo mulai dari usia 35-39 terdapat 9\%, usia 40-44 terdapat 55\% dan usia terdapat 45-49 36\%. Sehingga dapat dilihat bahwa usia pekerja wanita termasuk kedalam usia produktif. Banyaknya usia produktif memasuki sektor informal dipicu karena tidak adanya kriteri atau syarat khusus yang harus dipenuhi. Kemampuan dalam bekerja yang mereka miliki rata-rata bergerak di bidang perdagangan antara lain: membuat dan menjual tempe, gorengan, es es, sayuran, ikan, pakaian, sendal, dansepatu. 


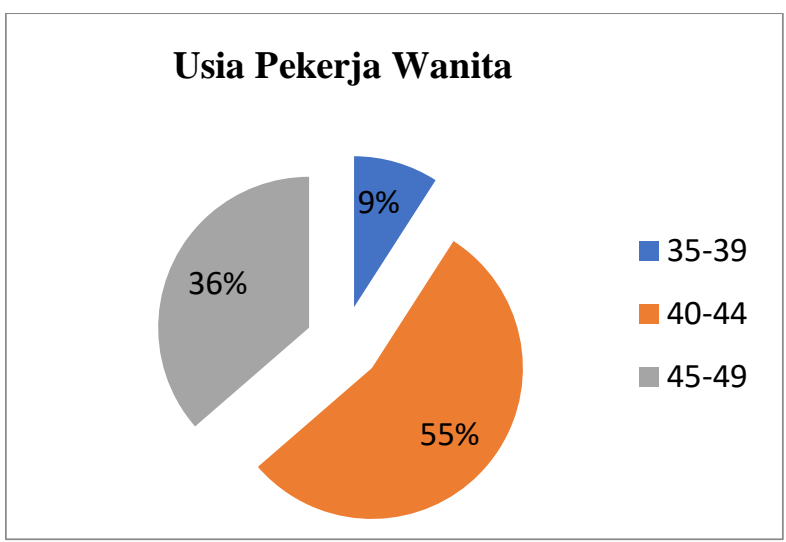

Gambar 1. Grafik Usia Pekerja Wanita

(Sumber : Analisis Data, 2019)

Para pekerja wanita sektor informal dalam penelitian ini mengatakan alasan ikut terjun kelapangan dan bekerja semata-mata hanya untuk membantu prekonomian keluarga. Seperti yang dinyatakan oleh salah satu informan yaitu "Saya bekerja disektor informal ini untuk memenuhi kebutuhan hidup sehari-hari", 02.m4a "pendapatan suami tidak mencukupi kebutuhan hidup baik membiayai makan dan anak sekolah jadi saya bekerja di sektor informal untuk memenuhi kebutuhan hidup keluarga", 08.m4a "Hasil pendapatan saya bekerja di sektor informal untuk bantu-bantu menambah pendapatan suami".

Pekerja wanita sektor informal disini ikut membantu prekonomian keluarga karena kecilnya pendapatan suami sedangkan kebutuhan hidup makin tahun terus meningkat sehingga mengharuskan mereka ikut membantu mencari nafkah. Menurut Artini dan Handayani (2009, dikutip dari Dewi, 2012:119-120) mengatakan bahwa umumnya perempuan termotivasi untuk bekerja adalah untuk membantu menghidupi keluarga dan umumnya bekerja di sektor informal.

\section{Pendidikan Pekerja Wanita Sektor Informal}

Pekerja wanita sektor informal dapat dilihat dari riwayat pendidikan yang mereka miliki. Pendidikan yang dimiliki seseorang terutama pekerja wanita sektor infornal dapat mempengaruhi atau sama sekali tidak berpengaruh terhadap pekerjaan dan juga pendapatan yang mereka peroleh. Pendidikan pekerja wanita sektor informal dapat diihat pada gambar 2.

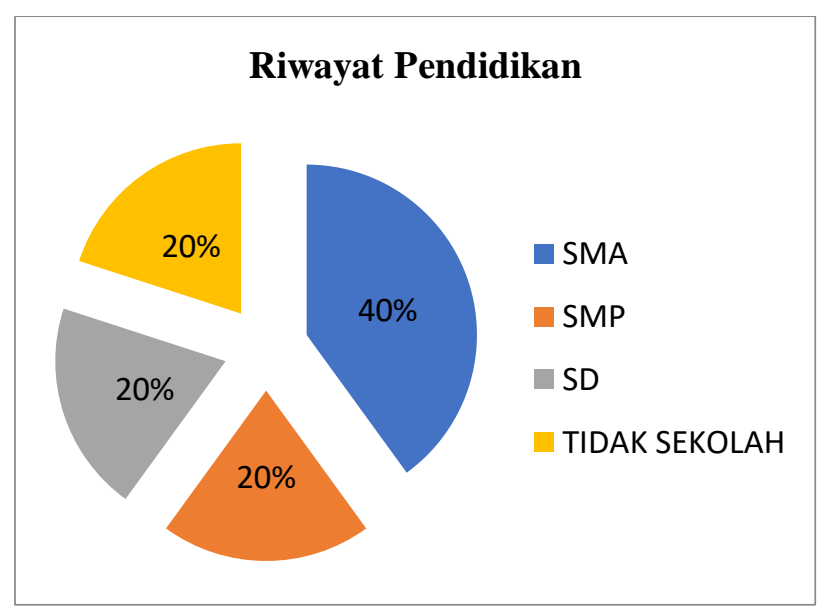

Gambar 2. Riwayat Pendidikan

(Sumber : Analisis Data, 2019)

Berdasarkan hasil survei lapangan diketahui bahwa pekerja wanita sektor informal $40 \%$ lulus SMA, 20\% lulus SMP, 20\% lulus SD dan $20 \%$ tidak sekolah. Hal ini dapat dilihat bahwa pekerja wanita sektor informal di Pasar Pendopo sebagian besar berpendidikan SMA. Berdasarkan hasil wawancara yang dilakukan pada salah satu informan mengatakan bahwa "banyaknya persaingan dalam mencari pekerjaan disektor formal mengaharuskannya memilih bekerja di sektor informal ditambah tingginya akan kebutuhan hidup.

Seperti halnya dalam penelitian (Taufik, Monanisa, Nengyanti, Soebyakto, \& Armansyah, 2019) tingginya akan kebutuhan hidup dalam rumah tangga dan juga diri sendiri menjadikan motivasi bagi wanita memasuki sektor informal. Memasuki pekerjaan di sektor formal bukan hanya terfokus pada satu syarat akan tetapi banyak hal seperti usia, pendidikan, skill, dan bahkan penampilan yang menarik tentunya yang harus dimiliki setiap masyarakat. Seperti yang katakan olehsalahsatu informal dilapangan "Untuk bekerja di sektor formal tentunya terbatasi oleh usia, sedangkan usia saya sudah 40 tahun selain itu pendidikan yang rendah dibandingkan anak jaman sekarang yang masih muda dan sarjana.

Bekerja di sektor informal memang merupakan jalan keluar bagi masyarakat terutama yang berpendidikan rendah, memang rata-rata pekerja wanita sektor informal disini berpendidikan SMA tetapi untuk di Kabupaten 
PALI ini terdapat banyak sarjana dengan usia 2230 tahun sedangkan berdasarkan dengan hasil penelitian bahwa usia pekerja wanita sektor informal di Pasar Pendopo ini diatas 30 tahun atau usia dewasa jelas dengan pendidikan hanya SMA mereka sulit untuk dapat pekerjaan yang lebih baik lagi. Menurut Suyanto (1996, dikutip dari Suyadi, 2010:8) bahwa mustahil bagi tenaga kerja tanpa memiliki pendidikan dan keterampilan akan terserap di sektor formal.

\section{Pendapatan Pekerja Wanita Sektor Informal}

Untuk memenuhi kebutuhan pokok keluarga, penghasilan memegang peranan penting karena seseorang melakukan pekerjaan adalah untuk mendapatakan penghasilan. Penghasilan yang diperoleh dimanfaatkan untuk memenuhi kebutuhan hidup seperti kebutuhan sehari-hari, kebutuhan sekolah anak dan kebutuhan sosial lainnya. Pendapatan pekerja wanita sektor informal dapat dilihat pada gambar 3.

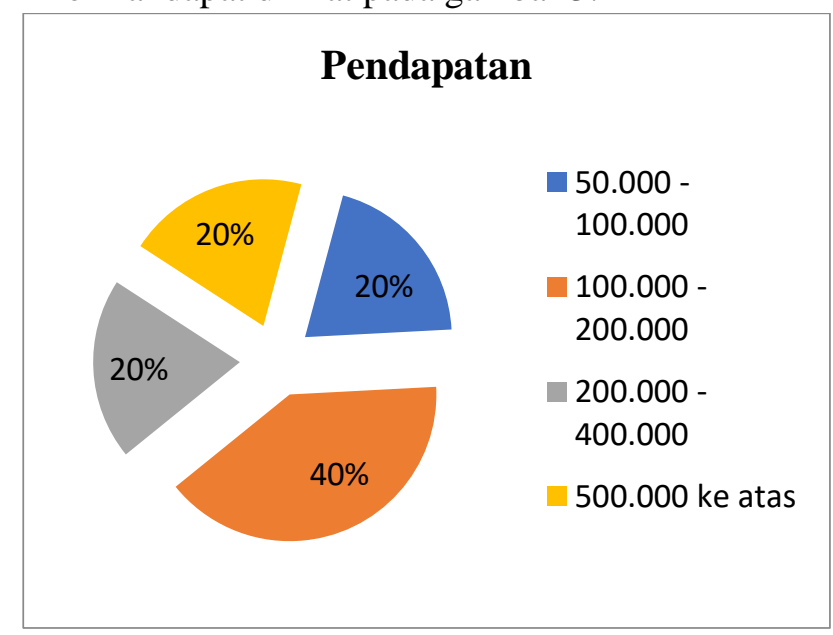

Gambar 3. Pendapatan Pekerja Wanita Sektor Informal (Sumber : Analisis Data, 2019)

Pendapatan pekerja wanita sektor informal hampir rata-rata berpenghasilan sebesar Rp. 100.000-200.000 perhari sebanyak 40 persen. Akan tetapi pekerja wanita sektor informal juga ada yang berpenghasilan sebesar Rp. 500.000 keatas perharinya sebanyak 20 persen. untuk pendapatan perhari Rp. 100.000 saja jika kita kalikan satu bulan berarti dalam sebulan pekerja wanita sektor informal ini mempunyai penghasilan Rp. 3.000.000 dengan kepemilikan usaha pekerja wanita sektor informal di Pasar Pendopo ini secara keseluruhan merupakan milik sendiri. Belum lagi jika penghasilan dari pekerja wanita sektor informal ini di tambah dengan pendapatan suami.

Terlebih pekerjaan suami dari pekerja wanita sektor informal disini yaitu wiraswasta, pedagang, petani, buruh dan bahkan ada di antara mereka sebagai pengangguran. Faktor-faktor inilah yang mengharuskan wanita untuk ikut berpartisipasi dalam bekerja agar kebutuhan keluarga terpenuhi. Meskipun ada beberapa suami dari pekerja wanita sektor informal ini sudah bisa mencukupi kebutuhan hidup sehari-hari, akan tetapi istrinya masih tetap ikut bekerja dengan alasan bosan dirumah tidak ada pekerjaan lain. Seperti hasil dari kutipan wawancara oleh 01.m4a " untuk masalah keuangan keluarga lebih senang ikut bekerja". Pendapatan pekerja wanita sektor informal disini digunakan untuk membantu memenuhi kebutuhan hidup sehari-hari, Seperti yang dikemukakan oleh informan 09.m4a "hasil pendapatan saya di pasar ini digunakan untuk biaya makan, anak sekolah, bayar listrik, bayar PAM".

Kondisi sosial ekonomi adalah semua yang berhubungan dengan pemenuhan kehidupan hidup sehari-hari dan kesejahteraan hidup masyarakat. Pada penelitian ini hal yang diteliti yaitu kondisi sosial ekonomi pekerja wanita sektor informal di Kecamatan Talang Ubi yang dikhususkan pada Pasar Pendopo Kelurahan Talang Ubi Timur Kecamatan Talang Ubi Kabupaten PALI.

Pasar Pendopo saat ini masih menjadi pusat pembelanjaan di Kabupaten PALI sehingga pada musim tertentu seperti libur sekolah atau menjelang lebaran terjadi kepadatan ditambah lagi trotoal jalan di padati oleh pedagang kaki lima dimana menambah persempit jalanan sehingga menyebabkan kemacetan di sekitaran Pasar Pendopo ini karena kendaraan-kendaraan yang terparkir sampai keluar area pasar.

Hasil penelitian di peroleh melalui teknik wawancara, observasi dan dokumentasi yang dilakukan di Pasar Pendopo Kelurahan Talang Ubi Timur Kecamatan Talang Ubi Kabupaten Pali pada bulan mei 2019. Wawancara yang digunakan pada penelitian ini adalah wawancara terstruktur dilakukakan pada 10 responden dan terdapat 19 
pertanyaan, jawaban yang diberikan oleh informan beragam seperti apa saja jenis dagangan yang didagangkan ada yang menjawab pedagang sayuran, buah, ikan, pakaian dan sandal sepatu, begitu juga saat di tanya berapa modal awal yang dibutuhkan, dimana jawabannya sesuai dengan jenis dagangan untuk pedagang sayuran, buah dan ikan dimulai dari Rp. 200.000-600.000,sedangkan untuk pedagang pakaian dan sandal sepatu Rp. 750.000-800.000,-.

Selain itu untuk berapa pendapatan perhari para pekerja wanita sektor informal ini secarakeseluruhan di atas Rp. 100.000,- perhari, apa pekerjaan suami para pekerja wanita sektor informal disini berbeda mulai dari petani, pedagang, buruh, pengangguran dan sudah meninggal dunia, kemudian untuk bagaimana pembagian pendapatan dengan suami rata-rata jawaban pekerja wanita disini adalah untuk membantu memenuhi kebutuhan hidup sehari-hari. Dan untuk apakah terdapat kendala selama berdagang di Pasar Pendopo ini kesimpulan jawaban dari ke 10 informan adalah cuaca dan persaingan serta apakah pernah mendapat bantuan dari pemerintah disini mendapatkan jawaban belum dan tidak pernah mendapat bantuan dari pemerintah.

\section{SIMPULAN}

Pekerja wanita sektor informal di Pasar Pendopo Kelurahan Talang Ubi Timur Kecamatan Talang Ubi Kabupaten PALI memiliki karakteristik berusia dari 30-49 tahun dan sudah menikah. Pekerja wanita yang berstatus menikah lebih cenderung memasuki sektor informal dibandingkan dengan pekerja wanita yang belum menikah, karena jumlah tanggungan dalam keluarga semakin tinggi sedangkan pendapatan suami secara keseluruhan tidak mencukupi kebutuhan hidup. Pekerja wanita disini tidak mempuyai pilihan lain selain bekerja pada sektor informal karena tingginya tingkat persaingan sedangkan pendidikan pekerja wanita sektor informal disini berpendidikan SMA. Selain itu, alasan dari pekerja wanita ini bekerja pada sektor informal karena pada sektor informal memiliki waktu yang fleksibel sehingga mereka dapat membagi waktu bekerja dan mengurus rumah tangga.

Berdasarkan hasil penelitian bahwa pendapatan dari pekerja wanita disini digunakan untuk membantu memenuhi kebutuhan hidup sehari-hari, karena semakin tahun kebutuhan hidup semakin meningkat. Dari pendapatan pekerja wanita sektor informal jika digabungkan dengan pendapatan suami mereka maka dapat dikatakan cukup untuk memenuhi kebutuhan hidup dari makan, pendidikan, kesehatan dan tempat tinggal. Sehingga dapat kita tarik kesimpulan kondisi sosial ekonomi pekerja wanita sektor informal di Pasar Pendopo Kecamatan Talang Ubi dapat digolongkan kedudukan sosial ekonomi menengah.

\section{DAFTAR PUSTAKA}

Arvenia, R. (2017). Kondisi Sosial Ekonomi Perkebunan Gaharu Di Desa Kotabaru Barat (Studi Pada Masyarakat Desa Kotabaru Barat Kecamatan Martapura Kabupaten Oku Timur Provinsi Sumatera Selatan): Skripsi, Lampung: Universitas Lampung.

Dewi, P.M. (2012). Partisipasi Tenaga Kerja Perempuan Dalam Meningkatkan Pendapatan Keluarga. Jurnal Ekonomi Kuantitatif Terapan. Volume 5(2): 119-124.

Ernawati, A. (2018). Hubungan Usia Dan Status Pekerjaan Ibu Dengan Kejadian Kurang Energi Kronis Pada Ibu Hamil. Jurnal litbang. Volume 14(1): 27-37.

Farida, L. (2011). Kontribus pendapatan Perempuan Bekerja Sektor Informal Pada Ekonomi Keluarga Di Kota Pekanbaru. Jurnal Aplikasi Bisnis. Volume 1(2): 103112.

Hakim. L. (2011). Perkembangan Tenaga Kerja Wanita Di Sektor Informal: Hasil Analis Dan Proxy Data Sensus Penduduk. jurnal Among Makarti. Volume 4(7): 20-32.

Handayani, S. (2009).Memahami Pelaku Sektor Informal Perkotaan. Jurnal Analisis Sosial. 
Volume 14(1): 33-53.

Hidayat.(2011). Peranan Sektor Informal Dalam Perekonomian Indonesia. Jurnal EKI. Volume 26(4): 415-445.

Taufik, M., Monanisa, Nengyanti, Soebyakto, B. B., \& Armansyah. (2019). Kontribusi Perempuan Pekerja Dalam Keluarga di Perkotaan. Eco-Build Journal , 3 (2), 3039.http://jurnal.stiemtanjungredeb.ac.id/index .php/ecobuild/article/view/395

Pitoyo, A.J. (2007). Dinamika Sektor Informal Di Indonesia Prospek, Perkembangan Dan Kedudukanya Dalam Sistem Ekonomi Makro. Jurnal Populasi. Volume 18(2): 129146.

Ramadhan, R. (2003). Perubahan Sosial-Ekonomi PKL (Pedagang Kaki Lima) Dalam Program Sentralisasi Sektor Informal Perkotaan DTC Wonokromo. Ringkasan Skripsi Yang Berjudul Sentralisasi Sektor Informal Perkotaan. Volume 1: 1-20.

Ramadhanti, Dina. Mulyadi, Hari. Razati, G.
(2016). Pengaruh Status Sosial Ekonomi Orang Tua Terhadap Sikap Wirausaha. Strategic-Jurnal Pendidikan Manajemen Dan Bisnis, 11(20), 32-37.

Suyadi, B. (2010). Peranan Sektor Informal Dalam Penyerapan Nelayan Di Wilayah Pantai Pasir Putih Situbondo. FKIP UNEJ, $1-14$.

Yudha, M.R.A. (2017). Analisis Kondisi Sosial Ekonomi Pedagang Sebelum Dan Sesudah Relokasi (Studi Kasus Pasar SMEP Tanjung Karang Kota Bandar Lampung): skripsi. Lampung: Universitas Lampung.

Yunus, A.I. (2011). Potret Kehidupan Sosial Ekonomi Pedagang Kaki Lima Di Kota Makasar (Kasus Penjual Pisang Epe Di Pantai Losari): skripsi. Makasar: universitas Hasanuddin.

Zunaidi, M. (2013). Kehidupan Sosial Ekonomi Pedagang di Pasar Tradisional Pasca Relokasi dan Pembangunan Pasar Modren. Sosiologi Islam , 3 (1), 51-64. 